\title{
ANALISIS KESALAHAN ESENSIAL HASIL PENGELASAN PESERTA LOMBA KOMPETENSI SISWA SMK TINGKAT DAERAH ISTIMEWA YOGYAKARTA
}

\author{
Putut Hargiyarto, Arif Marwanto, dan Riswan Dwi Djatmiko \\ Pendidikan Teknik Mesin Fakultas Teknik Universitas Negeri Yogyakarta \\ putut_hargi@uny.ac.id; redzupy@yahoo.com; riswan_dd@yahoo.co.uk
}

\begin{abstract}
The purpose of this study is to examine various defects in the welding joint works from the participants of Vocational High School students' skills competition in Yogyakarta area for welding field. This study can be categorized as a qualitative descriptive study. The data collection method was using documentation. The data was analyzed using descriptive qualitative technique. The results showed that in the preparation, the students were lack of understanding and knowledge in determining the welding requirements, the welding current, the type of electrodes SMAW. In the welding process, some participants did not fulfil the welding procedure during the welding process such as mistakes in setting up the SMAW machine, setting the welding current properly, selecting an electrode based on the type and thickness of the workpiece, and mistakes in the process offit up. In the post-welding process, there were a few mistakes such as the grinding process to clean weld spatter that damaged the ridge.
\end{abstract}

Keywords: $L K S$, Welding, SMAW

ABSTRAK

Tujuan penelitian ini untuk mengetahui berbagai kesalahan las pada sambungan las peserta lomba kompetensi siswa bidang pengelasan SMK se-DIY. Penelitian ini termasuk penelitian deskriptif kualitatif. Metode pengumpulan data dalam penelitian ini menggunakan dokumentasi. Data dianalisis dengan analis is deskriptif kualitatif. Hasil penelitian menunjukkan bahwa dalam persiapan, peserta masih kurang dalam: memahami persyaratan pengelasan, memilih arus pengelasan, dan mengetahui jenis elektroda SMAW. Dalam pengelasan masih terdapat beberapa peserta yang belum memenuhi prosedur pengelasan, yaitu kesalahan dalam set up mesin SMAW, mengatur arus pengelasan dengan benar, memilih elektroda sesuai dengan jenis dan ketebalan benda kerja, serta dalam proses fit up. Pasca pengelasan masih terdapat kesalahan yaitu, beberapa peserta yang menggerinda hasil kerja untuk membersihkan spatter sehingga merusak rigi las.

Kata kunci: LKS, Pengelasan, SMAW

\section{PENDAHULUAN}

Menurut Peraturan pemerintah Nomor 29 tahun 1990 pasal 1 ayat 2 pendidikan menengah kejuruan adalah pendidikan pada jenjang menengah yang menyiapkan peserta didik untuk memasuki lapangan kerja serta mengembangkan sikap profesional. Selanjutnya pada ayat 3 , pendidikan menengah kejuruan juga mengutamakan pengembangan kemampuan peserta didik untuk melaksanakan jenis pekerjaan tertentu. Dua hal mendasar dalam penyiapan lulusan pendidikan menengah kejuruan adalah tuntutan sikap profesional pada suatu pekerjaan tertentu. Karakteristik yang menonjol dari dua tuntutan tersebut adalah penyiapan anak didik masuk lapangan kerja sesuai kebutuhan dunia kerja berupa penguasaan pengetahuan, keterampilan, sikap dan nilai-nilai yang dibutuhkan dunia kerja (Djojonegoro, 1998:37).

Penyelenggaraan Lomba Kompetensi Siswa Sekolah Menengah Kejuruan (LKS SMK) Provinsi DIY Bidang Pengelasan merupakan wujud nyata salah satu upaya dalam pengembangan sumber daya manusia yang dilakukan oleh pemerintah melalui Dinas 
Pendidikan Pemuda dan Olahraga Provinsi DIY. LKS SMK Provinsi DIY Bidang Pengelasan adalah salah satu upaya mendorong SMK untuk meningkatkan kualitas pelaksanaan kegiatan belajar mengajar yang mengacu pada Standar Kompetensi Kerja Nasional Indonesia (SKKNI) khusus untuk Kompetensi Keahlian Teknik Pengelasan. Selain itu LKS SMK Provinsi DIY Bidang Pengelasan bertujuan untuk memantau peta kualitas dan kemampuan SMK di Provinsi DIY, terutama sekolah yang memiliki Kompetensi Keahlian Teknik Pengelasan. Namun pada pelaksanaannya LKS SMK Provinsi DIY bidang pengelasan belum bisa digunakan untuk melihat kemampuan SMK di Provinsi DIY yang memiliki
Kompetensi Keahlian Teknik Pengelasan. Hal ini disebabkan tidak banyaknya SMK yang memiliki Kompetensi Keahlian Teknik Pengelasan di Provinsi DIY yang berpartisipasi dalam pelaksanaan LKS SMK Provinsi DIY Bidang Pengelasan. Selain itu LKS SMK Provinsi DIY Bidang Pengelasan dijadikan agenda tahunan yang diselenggarakan untuk mempersiapkan perwakilan Provinsi DIY dalam agenda LKS tingkat Nasional Bidang Pengelasan. Hasil LKS Bidang Las Tingkat Provinsi DIY dalam lima tahun terakhir menunjukkan adanya kesenjangan yang menyolok di antara SMK, yang tercermin pada perolehan skor lomba, sebagaimana tabel berikut.

Tabel 1. Perolehan Skor LKS Bidang Las Tahun 2009 s.d. 2013

\begin{tabular}{lllllll}
\hline No & Nama Sekolah & 2009 & 2010 & 2011 & 2012 & 2013 \\
\hline 1 & SMK Muhammadiyah 2 Wates & 68,23 & 60 & 68,4 & 28 & 34,92 \\
2 & SMK Muh 3 Yogyakarta & 36,55 & 70,3 & 55,8 & 76 & 68,46 \\
3 & SMK Muhammadiyah Playen & 62,03 & 58,8 & 82,2 & 56,5 & 40,46 \\
4 & SMK MuhPrambanan & - & 51,3 & 32 & 26,3 & 40,46 \\
5 & SMK N 1 Pundong & - & 68 & 78 & 52,3 & 74,46 \\
6 & SMK N 1 Sedayu & 80,58 & 86,3 & 96,7 & 91,3 & 90,46 \\
7 & SMK N 1 Seyegan & 31 & 47,5 & 48,4 & 54,5 & 38,46 \\
8 & SMK N 2 Depok Sleman & 64,33 & 67,5 & 88,2 & 84,8 & 44 \\
9 & SMK N 2 Pengasih & 60,38 & 65,5 & 84,8 & 82,3 & 76 \\
10 & SMK N 2 Wonosari & 66,7 & 52 & 67,2 & 61,3 & 80,46 \\
11 & SMK N 2 Yogyakarta & 65,15 & 77,4 & 88,6 & 63 & 24,92 \\
12 & SMK N 3 Yogyakarta & 68,7 & 70,6 & 71,5 & 35,8 & 50 \\
13 & SMK Nasional Berbah, Sleman & 17,4 & - & - & - & - \\
14 & SMK PIRI 1 Yogyakarta & - & - & 59 & 52 & - \\
15 & SMK PIRI Sleman & - & - & - & 44,5 & - \\
& Rerata & 56,46 & 64,6 & 70,8 & 57,8 & 55,27 \\
\hline
\end{tabular}

Dari data di atas antara skor terendah dan tertinggi rentangnya sangat besar, hal ini merupakan indikasi belum meratanya kemampuan siswa wakil sekolah dalam LKS. Padahal peserta LKS adalah para siswa terbaik di sekolahnya, bagaimana dengan siswa lainnya? Kalau dilihat lebih jauh tentu kemampuan semua siswa di semua sekolah juga indikasinya serupa. Lebih jauh lagi bagaimana guru memberikan pembelajaran pengelasan disekolah. Hal ini tentu menjadi suatu permasalahan yang harus dipecahkan dalam rangka melaksanakan PBM praktik pengelasan yang mengacu kepada standar kompetensi dan teruji melalui kompetisi yang transparan dan akuntabel.

Oleh karena itu perlu dilakukan penelitian untuk melihat lebih jauh tentang kesalahan-kesalahan esensial yang dilakukan siswa saat melakukan pengelasan dalam mengikuti penyelenggaraan LKS. Hasil penelitian ini dapat dikembangkan menjadi bahan pertimbangan pengembangan metode pembelajaran pengelasan disekolah. Lebih jauh 
diharapkan dengan adanya pengembangan metode pembelajaran yang sama, diharapkan kemampuan siswa peserta LKS juga memiliki kemampuan setara.

Pengelasan merupakan penyambungan bahan dengan prinsip ikatan magnetik antar atom kedua bahan yang disambung. Kelebihan sambungan las adalah konstruksi ringan, dapat menahan kekuatan yang tinggi, mudah pelaksanaannya, serta cukup ekonomis. Namun kelemahan yang paling utama adalah terjadinya perubahan struktur mikro bahan yang dilas, sehingga terjadi perubahan sifat fisik maupun mekanis dari bahan yang dilas. Cara yang paling utama digunakan untuk memanasi logam yang dilas adalah arus listrik. Arus listrik dibangkitkan oleh generator dan dialirkan melalui kabel ke sebuah alat yang menjepit elektroda di ujungnya, yaitu suatu logam batangan yang dapat menghantarkan listrik dengan baik.
Ketika arus listrik dialirkan, elektroda disentuhkan ke benda kerja dan kemudian ditarik ke belakang sedikit, arus listrik tetap mengalir melalui celah sempit antara ujung elektroda dengan benda kerja. Arus yang mengalir ini dinamakan busur (arc) yang dapat mencairkan logam.

Terkadang dua logam yang disambung dapat menyatu secara langsung, namun terkadang masih diperlukan bahan tambahan lain agar deposit logam lasan terbentuk dengan baik, bahan tersebut disebut bahan tambah (filler metal). Filler metal biasanya berbentuk batangan, sehingga biasa dinamakan welding rod (Elektroda las). Pada proses las, welding rod dibenamkan ke dalam cairan logam yang tertampung dalam suatu cekungan yang disebut welding pool dan secara bersama-sama membentuk deposit logam lasan, cara ini dinamakan Las Listrik atau SMAW (Shielded metal Arch welding), lihat gambar 1.

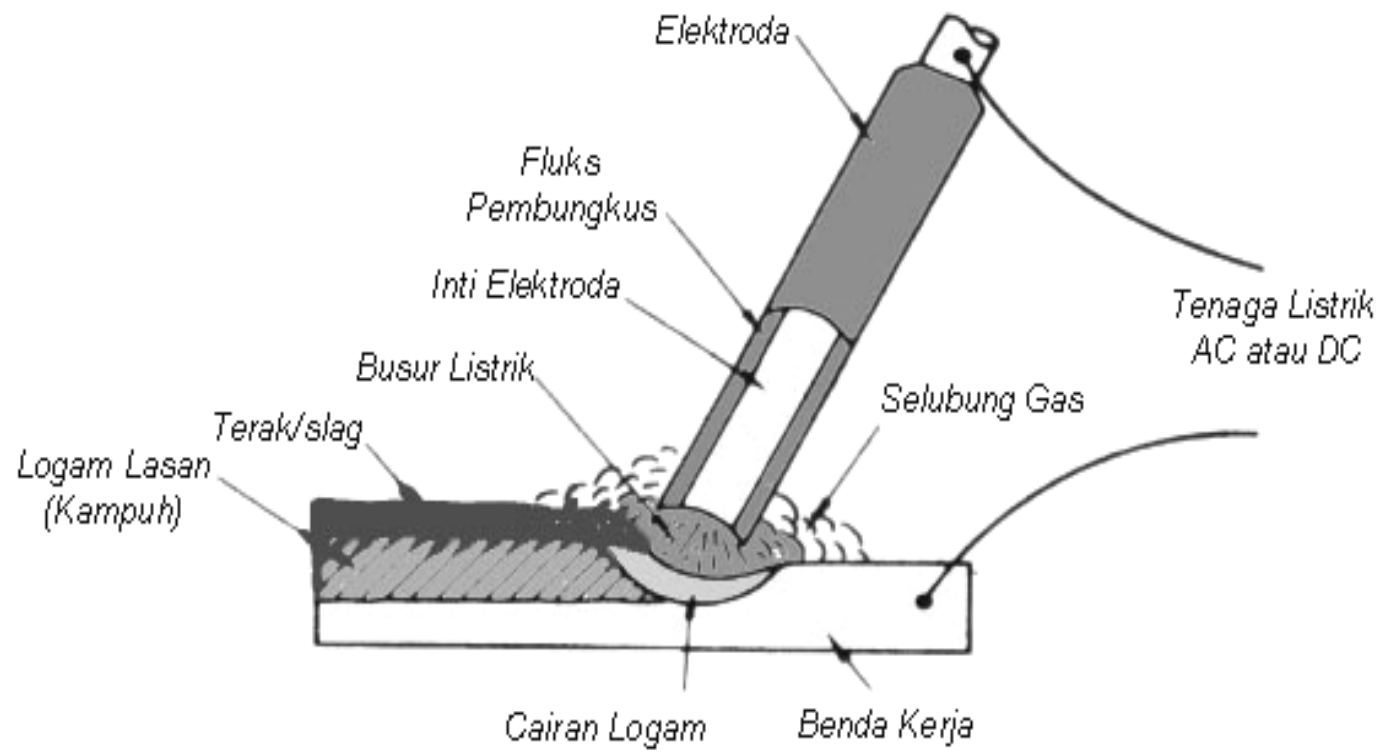

Gambar 1. Prinsip Kerja Las Listrik 
Selain SMAW, juga terdapat berbagai proses las. Tabel 2 berikut ini menunjukkan berbagai macam proses las yang ditinjau dari kelompok SSW dan LSW, di samping itu juga dilihat dari jenis sumber panas yang digunakan beserta kode proses las berdasarkan standar ISO.

Tabel 2. Klasifikasi Proses Pengelasan Logam

\begin{tabular}{|c|c|c|c|c|c|}
\hline & & & & $\begin{array}{c}\text { Jenis } \\
\text { Proses Las }\end{array}$ & $\begin{array}{l}\text { Kode } \\
\text { ISO }\end{array}$ \\
\hline \multirow{16}{*}{ 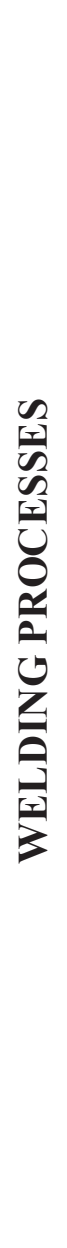 } & \multirow{11}{*}{ 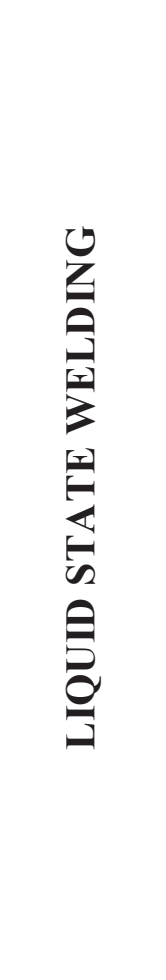 } & \multirow{2}{*}{\multicolumn{2}{|c|}{ Flash Butt }} & Stud Welding & 781 \\
\hline & & & & Projection Welding & \\
\hline & & \multirow{6}{*}{ 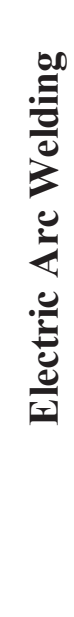 } & \multirow{4}{*}{ Consumable Electrode } & $\begin{array}{l}\text { Shelded Metal Arc } \\
\text { Welding (SMAW) }\end{array}$ & 111 \\
\hline & & & & $\begin{array}{c}\text { Metal Inert Gas Welding } \\
\text { (MIG) }\end{array}$ & 131 \\
\hline & & & & $\begin{array}{l}\text { Metal Active Gas } \\
\text { Welding (MAG) }\end{array}$ & 135 \\
\hline & & & & $\begin{array}{c}\text { Flux Cored Arc Welding } \\
\text { (FCAW) }\end{array}$ & 114 \\
\hline & & & \multirow{2}{*}{$\begin{array}{l}\text { Non Consumable } \\
\text { Electrode }\end{array}$} & $\begin{array}{c}\text { Tungsten Inert Gas } \\
\text { (TIG) }\end{array}$ & 141 \\
\hline & & & & $\begin{array}{c}\text { Plasma Arc Welding } \\
\text { (PAW) }\end{array}$ & 15 \\
\hline & & \multicolumn{2}{|r|}{ Resistance Welding } & $\begin{array}{l}\text { Spot Welding } \\
\text { Seam Welding }\end{array}$ & \\
\hline & & \multirow{2}{*}{\multicolumn{2}{|c|}{ Thermal Welding }} & Gas Welding & 3 \\
\hline & & & & Laser Welding & - \\
\hline & \multirow{5}{*}{ 奉息苗 } & \multicolumn{3}{|c|}{ Friction Welding } & 42 \\
\hline & & \multirow{2}{*}{\multicolumn{2}{|c|}{ Cold Welding }} & Explosive Welding & 441 \\
\hline & & & & Ultrasonic Welding & 41 \\
\hline & & \multicolumn{3}{|c|}{ Forge Welding } & 43 \\
\hline & & \multicolumn{3}{|c|}{ Diffusion Welding } & 45 \\
\hline
\end{tabular}


Pada pengelasan Shielded Metal Arc Welding (SMAW) transformator yang merupakan bagian utama mesin SMAW dirancang atas dasar constant current (CC), dengan sistim ini transformator menghasilkan kurva output volt-ampere sebagaimana Gambar 2 berikut.

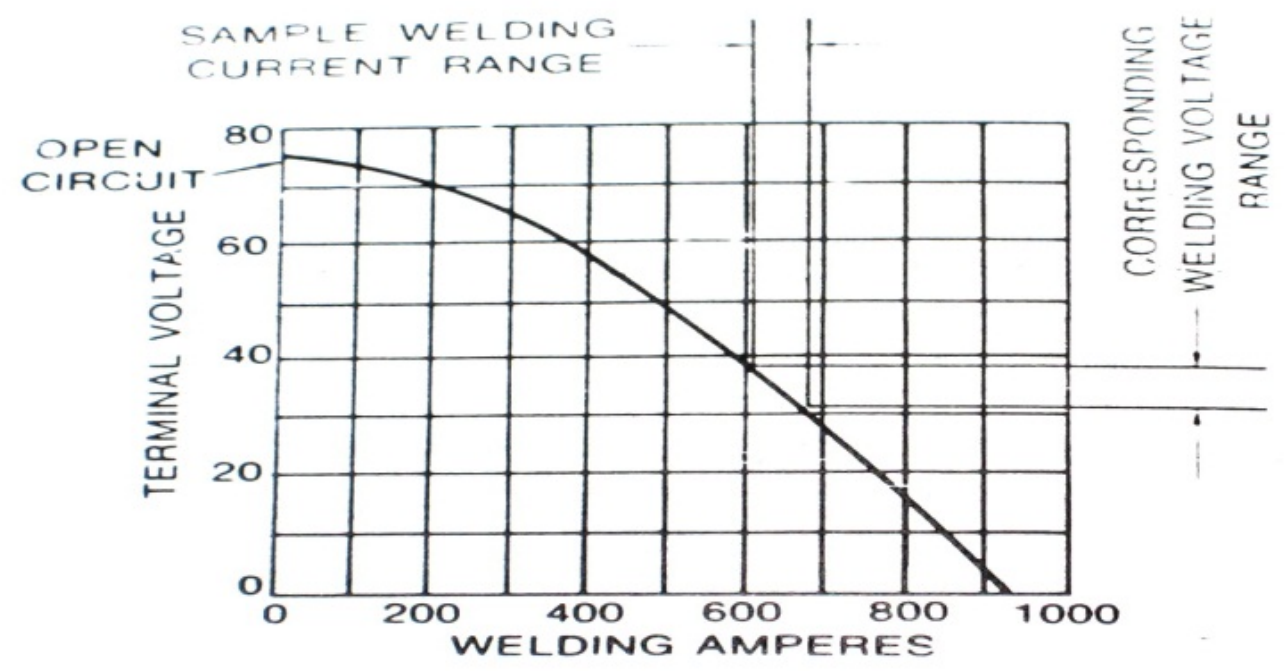

Gambar 2. Kurva Constant Current (Kennedy, 2004:234)

Jika kurva dalam gambar 2 dianalisis, transformator menghasilkan tegangan maksimum pada saat arus listrik nol ampere dan tegangan akan berkurang ketika arus listrik bertambah. Variasi hubungan antara tegangan dengan arus ini mengakibatkan panas yang ditimbulkan oleh busur listrik juga mengalami perubahan. Perubahan panas ini tergantung besar jarak antara benda kerja dengan elektroda. Menurut Kennedy (2004:235), "Without changing the machine setting, the operator can vary the welding heat by lengthening or shortening the arc". Keberhasilan pengelasan logam dengan SMAW tergantung pada parameter las, prosedur, dan juru las (welder). Parameter las meliputi tegangan, arus, dan panjang busur yang pengaturannya sangat tergantung pada juru las. Teknik pengelasan dengan SMAW terdiri dari tiga langkah, menurut Kennedy (2004: 242-245) langkah tersebut adalah: preparation, striking, dan weaving. Preparation adalah pembersihan benda kerja dari kotoran yang berupa lemak dan lapisan oksida. Striking mempunyai pengertian penyalaan awal elektroda yang dilakukan dengan metode gores (scratching method) untuk mesin las $\mathrm{AC}$ dan metode hentak (tapping method) untuk mesin las DC. Weaving atau pengayunan elektroda las berguna untuk membentuk deposit logam las agar memiliki bentuk yang disyaratkan.

\section{Menurut Standard Operational} Procedure (SOP) yang dikeluarkan oleh Hobart School of Welding Technology (2005: 8-11), ada lima langkah yang harus dilakukan oleh mahasiswa yaitu: 1) Get ready; 2) Set machine; 3) Position material; 4) Strike arc; dan 5) Bead weld practice. Kualitas hasil las yang dihasilkan oleh Bead weld practice tergantung pada penguasaan Strike arc (penyalaan awal). Penyalaan awal elektroda menjadi faktor yang sangat penting dalam menentukan kualitas sambungan las, hal ini karena karakteristik mesin SMAW yang berprinsip pada sistim CC yang memaksa mereka untuk menjaga panjang busur listrik pada posisi yang tepat sangat sulit dilakukan karena mereka termasuk pemula dalam belajar las.

Hambatan yang mendasar yang dialami untuk menghasilkan sambungan las yang berkualitas adalah sulitnya menjaga panjang busur nyala elektroda pada posisi yang tepat 
karena belum memahami karakteristik busur nyala. Untuk memahami karakteristik busur nyala tersebut diperlukan metode pembelajaran yang tepat yang dapat memberikan pengalaman sendiri melalui praktik pengaturan panjang busur nyala agar ditemukan posisi yang tepat dan menghasilkan sambungan las yang berkualitas. Tidak semua juru las mahir di semua posisi, posisi di bawah tangan (down hand) merupakan posisi yang paling mudah untuk dilakukan, namun ketika mengelas pipa logam dengan posisi miring akan sangat sulit dilakukan. Juru las yang dapat melakukan pengelasan ini adalah juru las kelas satu yang dilengkapi dengan sertifikat standar internasional. Metode pengelasan logam yang meliputi prosedur pengelasan, prosedur perlakuan panas, desain sambungan, serta teknik pengelasan disesuaikan dengan jenis bahan, peralatan, serta posisi pengelasan saat sambungan las dibuat. Aspek efektifitas, efisiensi proses, dan pertimbangan ekonomis berkaitan erat dengan pemilihan peralatan las. Pengelasan logam stainless steel akan berkualitas bagus jika menggunakan las TIG, namun akan lebih murah bila dilas dengan las listrik, sehingga pemilihan mesin dan peralatan las sebaiknya disesuaikan dengan tujuan pengelasan serta biaya operasionalnya.

Penyelenggaraan Lomba Kompetensi Siswa Sekolah Menengah Kejuruan (SMK) seluruh Indonesia merupakan wujud nyata salah satu upaya dalam pengembangan sumber daya manusia yang dilakukan oleh pemerintah melalui Direktur Pembinaan SMK - Direktorat Jenderal Pendidikan Menengah. Hal ini didasarkan atas tantangan masa depan dalam era globalisasi yang memberikan dampak ganda yaitu: pertama membuka kesempatan kerjasama yang seluas-luasnya antar daerah ataupun antar Negara, kedua membuka persaingan yang semakin ketat dan tajam di segala bidang pekerjaan. Untuk menghadapi tantangan tersebut diatas, maka pemerintah harus memperkuat daya saing dan keunggulan kompetitif di semua sektor dengan mengandalkan pada kualitas dan kemampuan sumber daya manusia dengan penguasaan teknologi dan manajemen. Untuk itu pemerintah selalu berusaha menyiapkan tenaga kerja yang kompeten dalam bidangnya masingmasing, salah satunya ialah dengan Lomba Keterampilan Siswa (Kemdikbud, 2012:1). Dalam tata urutannya, LKS dilaksanakan berjenjang mulai dari regional (beberapa daerah tingkat 2) kemudian tingkat propinsi dan masing masing juara dikirim ke LKS tingkat nasional.

Adapun tujuan penyelenggaraan LKS adalah untuk:

a. Mendorong SMK untuk meningkatkan kualitas pelaksanaan kegiatan belajar mengajar yang mengacu pada Standar Kompetensi Kerja Nasional Indonesia (SKKNI) khusus untuk Kompetensi Keahlian Teknik Pengelasan

b. Untuk memantau peta kualitas dan kemampuan SMK di seluruh Indonesia, terutama sekolah yang memiliki Kompetensi Keahlian Teknik Pengelasan

c. Mempromosikan kompetensi siswa SMK untuk Kompetensi Keahlian Teknik Pengelasan kepada dunia usaha dan industri sebagai calon pengguna tenaga kerja

d. Memberikan kesempatan dan motivasi kepada siswa untuk berkompetisi secara positif, untuk menumbuhkan kebanggaan pada kompetensi keahlian yang ditekuninya, juga kebanggaan bagi sekolah dan daerah/provinsinya.

Peserta LKS adalah siswa SMK dengan kriteria sebagai berikut :

a) Warga Negara Kesatuan Republik Indonesia

b) Tercatat sebagai siswa SMK negeri atau swasta dengan Kompetensi Keahlian Teknik Pengelasan (Teknik Las) di Indonesia

c) Dinyatakan sebagai pemenang LKS Tingkat Provinsi Kompetensi Keahlian Teknik Pengelasan atau yang ditunjuk oleh Kepala Dinas pendidikan Nasional sebagai peserta LKS Tingkat Nasional mewakili provinsi yang bersangkutan 
d) Setiap provinsi hanya dapat diwakili oleh 1 (satu) orang peserta

e) Sehat jasmani dan rohani (tidak dalam kondisi sakit).

Materi lomba bidang pengelasan diambil berdasarkan kurikulum Sekolah Menengah
Kejuruan, Kompetensi Keahlian Teknik Pengelasan (Teknik Las). Selanjutnya materi yang akan dilombakan pada Lomba Kompetensi Siswa sebagaimana dalam tabel dibawah ini :

Tabel 3. Materi Lomba LKS Las

\begin{tabular}{|c|c|c|c|}
\hline NO & TUGAS/TAS K & BOBOT & WAKTU \\
\hline 1 & $\begin{array}{c}\text { Pengelasan Pipa Baja Karbon Rendah Sambungan Tumpul V, } \\
\text { Posisi Multyple } 90^{\circ} \text { (5-G) Oneside Full Penetration dengan } \\
\text { Proses SMAW }\end{array}$ & $50 \%$ & \\
\hline 2 & $\begin{array}{c}\text { Pengelasan Pelat Baja Lunak Sambungan Tumpul V, Posisi } \\
\text { Tegak/vertical (3-G) Jalur Las } 45^{\circ} \text { Oneside Full Penetration } \\
\text { dengan Proses Kombinasi SMAW dan GMAW (las akar/root } \\
\text { dengan proses SMAW, las isi/fill dan penutup/capping dengan } \\
\text { proses GMAW/MAG) }\end{array}$ & $30 \%$ & $\begin{array}{l}\text { Total } 4 \text { jam } \\
\text { (240 menit) }\end{array}$ \\
\hline 3 & $\begin{array}{c}\text { Pengelasan Pelat Baja Lunak Sambungan T, Posisi Vertical Up } \\
\text { (3-F) dengan Proses GMAW (2 Layer - } 2 \text { Pass) }\end{array}$ & $20 \%$ & \\
\hline
\end{tabular}

\section{METODE}

Untuk melaksanakan penelitian ini ditempuh dengan metode deskriptif kuantitatif, bertujuan untuk menjelaskan fenomena yang terjadi pada objek penelitian yaitu hasil sambungan las siswa peserta LKS tingkat DIY. Penelitian ini dilakukan untuk memahami fenomena ketimpangan kompetensi pengelasan siswa peserta LKS pengelasan tingkat DIY. Pengumpulan data dilakukan dengan analisis dokumen berupa benda kerja hasil sambungan las dengan jenis sambungan groove posisi horisontal (2G) dan posisi vertikal (3G). Data yang dihasilkan bersifat deskriptif guna mengungkapkan sebab dan proses terjadinya peristiwa yang dialami oleh subjek penelitian. Pelaksanaan penelitian dilakukan dengan langkah-langkah sebagai berikut :

1. Menyusun lembar observasi berupa lembar penilaian berdasarkan standar prosedur penilaian sambungan las.

2. Mengelompokkan data yang diperoleh berdasarkan pada langkah-langkah/prose-dur standar pengelasan.

3. Menganalisis data sesuai dengan data yang diperoleh, melalui analisis kuantitatif.

4. Menyimpulkan hasil analisis.

Subyek sekaligus populasi penelitian ini adalah hasil pengelasan siswa SMK peserta LKS pengelasan tingkat DIY tahun 2012 dan 2013. Waktu penelitian selama 6 bulan mulai bulan April s.d. September 2014. Data dikumpulkan dengan teknik observasi dengan menganalisis benda kerja hasil LKS pengelasan ke SMK, lembar observasi dikembangkan oleh peneliti mengacu pedoman standar penilaian hasil pengelasan. Analisis data menggunakan teknik analisis deskriptif kuantitatif, dengan menghitung frekuensi macam kesalahan prosedural, kemudian dihitung rerata, dan persentasenya, kemudian disimpulkan secara kualitatif mengacu kepada terbangunnya jawaban terhadap rumusan masalah. 
Tabel 4. Kisi-kisi Instrumen Penilaian Hasil Las

\begin{tabular}{|c|c|c|}
\hline Indikator & Sub Indikator & $\begin{array}{l}\text { Nomor } \\
\text { Soal }\end{array}$ \\
\hline \multirow{14}{*}{$\begin{array}{l}\text { Kebebasan } \\
\text { benda kerja } \\
\text { dari barbagai } \\
\text { cacat las }\end{array}$} & Kebebasan benda kerja dari slag, smoke, \& Spatter (lebih dari 99\%) & 1 \\
\hline & Kebebasan dari arc stray & 2 \\
\hline & Variasi lebar beadd tidak melebihi $2 \mathrm{~mm}$ & 3 \\
\hline & $\begin{array}{l}\text { Perbedaan ketinggian stop-start pada permukaan cover pass \& root pass } \\
\text { tidak melebihi } 1,5 \mathrm{~mm}\end{array}$ & 4,5 \\
\hline & $\begin{array}{l}\text { Kebebasan benda kerja dari cacat visual inclution }(1 \text { cacat }=0,2 ; 2 \\
\text { cacat }=0,2 ; 3 \text { cacat }=0 ; \text { tidak ada cacat }=0,3)\end{array}$ & 6 \\
\hline & $\begin{array}{l}\text { Kebebasan benda kerja dari cacat porosity }(1 \text { cacat }=0,2 ; 2 \text { cacat }=0,2 ; 3 \\
\text { cacat }=0 ; \text { tidak ada cacat }=0,3)\end{array}$ & 7 \\
\hline & Kebebasan benda kerja dari cacat undercutt dengan kedalaman lebih dari & \\
\hline & $\begin{array}{l}0,5 \mathrm{~mm} \text {, jika kurang }(1 \text { cacat }=0,2 ; 2 \text { cacat }=0,2 ; 3 \text { cacat }=0 ; \text { tidak ada } \\
\text { cacat }=0,3) \text { setiap } 10 \mathrm{~mm} \text { panjang }=1 \text { cacat }\end{array}$ & 8 \\
\hline & $\begin{array}{l}\text { Kebebasan benda kerja dari cacat incomplete penetration or root fusion } \\
\text { porosity dan excesive penetration }(1 \text { cacat }=0,2 ; 2 \text { cacat }=0,2 ; 3 \text { cacat }=0 ; \\
\text { tidak ada cacat }=0,3) \text { setiap panjang } 10 \mathrm{~mm}=1 \text { cacat }\end{array}$ & 9,10 \\
\hline & $\begin{array}{l}\text { Kebebasan benda kerja dari cacat root concavity or suck back yang } \\
\text { kedalamannya lebih dari } 5 \mathrm{~mm} \text {. }(1 \text { cacat }=0,2 ; 2 \text { cacat }=0,2 ; 3 \text { cacat }=0 \text {; } \\
\text { tidak ada cacat }=0,3) \text { setiap panjang } 10 \mathrm{~mm}=1 \text { cacat }\end{array}$ & 11 \\
\hline & Kebebasan benda kerja dari cacat underfill (tak ada cacat=0,3 mm) & 12 \\
\hline & $\begin{array}{l}\text { Kebebasan benda kerja dari cacat excessive face reinforcement }(1 \\
\text { cacat }=0,2 ; 2 \text { cacat }=0,2 ; 3 \text { cacat }=0 \text {; tidak ada cacat }=0,3) \text { setiap panjang } 10 \\
\mathrm{~mm}=1 \text { cacat }\end{array}$ & 13 \\
\hline & $\begin{array}{l}\text { Kebebasan benda kerja dari cacat angular distortion lebih dari } 3 \text { derajat } \\
\text { (tidak ada cacat }=0,2 \mathrm{~mm} \text { ) }\end{array}$ & 14 \\
\hline & Kebebasan benda kerja dari cacat missalignment lebih dari $2,5 \mathrm{~mm}$ & 15 \\
\hline
\end{tabular}

\section{HASIL DAN PEMBAHASAN}

Hasil penelitian yang diperoleh dalam penelitian ini berupa data mengenai hasil Lomba Kompetensi Siswa Sekolah Menengah Kejuruan (LKS-SMK) Daerah Istimewa Yogyakarta (DIY) Bidang Pengelasan. Data hasil LKS berupa penilaian hasil pengelasan sedangkan untuk teori tidak dibahas dalam penelitian ini.

\section{Pelaksanaan Tahun 2012}

LKS-SMK Bidang Las Provinsi DIY Tahun 2012 diikuti 14 peserta yang berasal dari SMK se-Daerah Istimewa Yogyakarta. LKSSMK Bidang Las Provinsi DIY Tahun 2012 Job yang dikerjakan adalah membuat sambungan kampuh "V" (V Butt Joint) posisi vertikal up (3G). Berikut data hasil LKS bidang pengelasan tahun 2012. 
Tabel 5. Penilaian Hasil Pekerjaan Sambungan Las LKS 2012

\begin{tabular}{|c|c|c|c|c|c|c|c|c|c|c|c|c|c|c|c|}
\hline \multirow{2}{*}{ No. } & \multirow{2}{*}{$\begin{array}{c}\text { Skor } \\
\text { Maks }\end{array}$} & \multicolumn{14}{|c|}{ Nomor Urut Pes erta } \\
\hline & & 1 & 2 & 3 & 4 & 5 & 6 & 7 & 8 & 9 & 10 & 11 & 12 & 13 & 14 \\
\hline 1 & 0,2 & 0,2 & 0 & 0,2 & 0 & 0 & 0,2 & 0,2 & 0,2 & 0 & 0 & 0,2 & 0 & 0 & 0,2 \\
\hline 2 & 0,2 & 0 & 0 & 0 & 0 & 0 & 0 & 0,2 & 0 & 0 & 0 & 0,2 & 0 & 0 & 0,2 \\
\hline 3 & 0,3 & 0 & 0 & 0,3 & 0 & 0 & 0 & 0,3 & 0,3 & 0 & 0 & 0,3 & 0,3 & 0 & 0 \\
\hline 4 & 0,2 & 0 & 0 & 0 & 0 & 0 & 0,2 & 0,2 & 0,2 & 0 & 0 & 0 & 0,2 & 0 & 0,2 \\
\hline 5 & 0,3 & 0,3 & 0 & 0,3 & 0 & 0,3 & 0,3 & 0,3 & 0,3 & 0 & 0 & 0,3 & 0 & 0,3 & 0,3 \\
\hline 6 & 0,3 & 0 & 0,1 & 0 & 0 & 0 & 0,1 & 0,1 & 0,3 & 0 & 0 & 0,3 & 0,3 & 0,2 & 0,3 \\
\hline 7 & 0,3 & 0,3 & 0,1 & 0,3 & 0,2 & 0 & 0,1 & 0,3 & 0,3 & 0 & 0 & 0,3 & 0,3 & 0,3 & 0,3 \\
\hline 8 & 0,3 & 0 & 0 & 0,3 & 0 & 0 & 0,1 & 0,3 & 0,2 & 0 & 0 & 0,3 & 0,2 & 0,3 & 0,3 \\
\hline 9 & 0,3 & 0 & 0 & 0 & 0 & 0,3 & 0,3 & 0,3 & 0,2 & 0 & 0 & 0,2 & 0 & 0 & 0,3 \\
\hline 10 & 0,3 & 0,3 & 0 & 0,3 & 0 & 0,3 & 0,3 & 0,3 & 0,2 & 0 & 0,3 & 0,2 & 0 & 0,3 & 0,3 \\
\hline 11 & 0,3 & 0,3 & 0,3 & 0 & 0,3 & 0,3 & 0,2 & 0,3 & 0,3 & 0 & 0 & 0,3 & 0 & 0,3 & 0,3 \\
\hline 12 & 0,3 & 0 & 0 & 0,3 & 0 & 0 & 0 & 0,3 & 0,3 & 0 & 0 & 0,3 & 0,3 & 0,3 & 0,3 \\
\hline 13 & 0,3 & 0 & 0 & 0 & 0,3 & 0,3 & 0,3 & 0 & 0 & 0 & 0 & 0 & 0 & 0 & 0,3 \\
\hline 14 & 0,2 & 0,2 & 0,2 & 0 & 0,2 & 0,2 & 0,2 & 0,2 & 0,2 & 0,2 & 0,2 & 0,2 & 0,2 & 0,2 & 0,2 \\
\hline 15 & 0,2 & 0,2 & 0,2 & 0,2 & 0,2 & 0,2 & 0,2 & 0,2 & 0,2 & 0,2 & 0,2 & 0,2 & 0,2 & 0,2 & 0,2 \\
\hline \multicolumn{2}{|c|}{ Jumlah } & 1,8 & 0,9 & 2,2 & 1,2 & 1,9 & 2,5 & 3,5 & 3,2 & 0,4 & 0,7 & 3,3 & 2 & 2,4 & 3,7 \\
\hline \multicolumn{2}{|c|}{ Nilai } & 45 & 22,5 & 55 & 30 & 47,5 & 62,5 & 87,5 & 80 & 10 & 17,5 & 82,5 & 50 & 60 & 92,5 \\
\hline
\end{tabular}

Dari tabel hasil las LKS-SMK Bidang Las Provinsi DIY Tahun 2012 di atas terlihat beberapa butir penilaian hasil las yaitu membuat sambungan kampuh "V" posisi 3G, peserta yang lulus tidak lebih dari setengah jumlah peserta yang mengikuti LKS-SMK Bidang Las Provinsi DIY Tahun 2012, seperti yang ditampilkan digambar berikut:

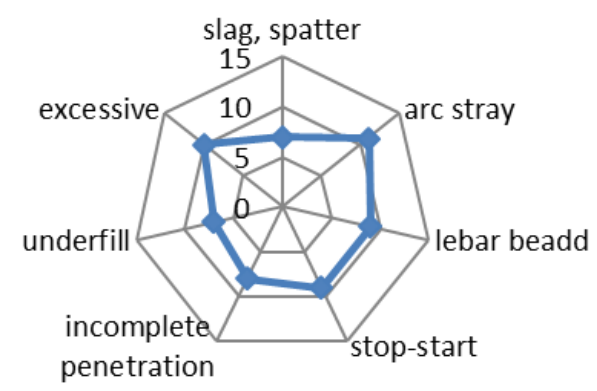

Gambar 5. Diagram Kesalahan yang Banyak Terjadi pada Hasil Las 3G

Gambar di atas menunjukkan bahwa kesalahan yang banyak dilakukan peserta LKSSMK Bidang Las Provinsi DIY Tahun 2012 yakni membuat sambungan kampuh "V" posisi vertical up (3G) meliputi beberapa kesalahan atau cacat seperti dijelaskan di bawah ini:

\section{a. Ke be basan benda kerja dari Slag, Smoke, dan Spatter.}

Dari diagram di atas terlihat setengah dari jumlah peserta LKS-SMK Bidang Las Provinsi DIY Tahun 2012 yang hasil lasnya bebas dari slag, smoke, dan spatter. Hal ini menunjukkan bahwa masih banyak peserta 
yang belum memenuhi kriteria hasil las bebas dari Slag, smoke dan spatter. Cacat ini disebabkan oleh arus yang terlalu besar, salah jenis arus, dan salah polaritas. Oleh karena itu, pemilihan dan penentuan arus yang tepat akan mengurangi terjadinya slag dan spatter.

\section{b. Kebebas an dari Arc stary}

Dari diagram di atas terlihat bahwa hasil pengelasan peserta yang bebas dari arc stray hanya 1 orang, sementara 11 hasil pengelasan dari peserta lain terdapat arc stray. Arc stray merupakan cacat las yang terjadi pada saat proses menyalakan elektroda. Kesalahan ini dapat menyebabkan rusaknya benda kerja, oleh karena itu kesalahan ini harus dihindari.

\section{c. Variasi le bar Beadd tidak me le bihi $2 \mathrm{~mm}$.}

Dari diagram di atas terlihat bahwa peserta yang lulus pada butir 3 yaitu variasi lebar beadd tidak melebihi $2 \mathrm{~mm}$ hanya 3 orang, sedangkan yang lulus 9 orang. Ini menunjukkan bahwa mayoritas peserta belum memenuhi kriteria lebar beadd dengan toleransi $2 \mathrm{~mm}$. Kesalahan las ini desebabkan oleh tidak stabilnya gerakan/ayunan peserta saat melakukan pengelasan terutama pada saat mengelas cover pass. Untuk menghindari kesalahan ini dapat dilakukan dengan memperkuat tumpuan tangan dalam memegang elektroda pada saat mengelas serta membiasakan diri dengan membuat gerakan/ayunan yang stabil.

\section{d. Ketinggian Stop-start pada permukaan Cover Pass.}

Dari diagram di atas diketahui bahwa 9 peserta LKS-SMK Bidang Las Provinsi DIY tidak lulus dalam penilaian hasil pada butir ini yakni ketinggian stop-start pada permukaan cover pass. Perbedaan ketinggian stop-start pada permukaan cover pass ini biasa terjadi karena memang butuh keahlian khusus untuk menghasilkan hasil pengelasan SMAW rata dan halus pada setiap sambungan ketika proses mengelas membutuhkan sambungan karena keterbatasan panjang elektroda. Perbedaan ketinggian stop-start ini biasanya terjadi karena pada saat melakukan pengelasan lagi setelah mengganti elektroda temperatur benda kerja menurun dan ketika melakukan pengelasan lagi seharusnya dilakukan pemanasan awal untuk meningkatkan temperatur sehingga pencairan elektroda bisa benar-benar menyatu dengan benda kerja.

\section{e. Cacat incomplete penetration.}

Dari diagram di atas terlihat 8 hasil pengelasan dari peserta LKS-SMK Bidang Las Provinsi DIY Tahun 2012 terdapat cacat incomplete penetration. Kesalahan ini terjadi pada pengelasan root pass yang kurang sempurna atau tidak tembus. Hal ini bisa disebabkan letak elektroda sewaktu pengelasan pertama terlalu tinggi, dan arus yang dipakai terlalu rendah. Selain itu, jarak sisi-sisi kampuh (root gap) terlalu rapat juga dapat menjadi penyebab tidak sempurnanya tembusan yang dihasilkan.

\section{f. Ke bebas an dari cacat under fill.}

Dari diagram di atas terlihat setengah hasil pengelasan dari jumlah peserta LKS-SMK Bidang Las Provinsi DIY Tahun 2012 mengalami cacat underfill. Kesalahan ini merupakan kesalahan yang terjadi pada permukaan las (cover pass) tidak penuh atau di bawah permukaan benda kerja. Hal ini terjadi karena cover pass dilakukan dengan gerakan terlalu cepat. Selain itu, juga bisa disebabkan karena pengelasan pada saat filler pass masih kurang

\section{g. Kebebasan dari Excessive Face Reinforcement.}

Dari diagram di atas dapat dilihat bahwa 10 dari 12 hasil pengelasan mengalami cacat excessive face reinforcement. Cacat ini adalah dapat dilihat dari terlalu tingginya beberapa bagian permukaan pengelasan. Kesalahan ini terjadi akibat tidak stabilnya jarak elektroda dengan benda kerja sehingga ketika elektroda terlalu dekat maka yang terjadi hasil pengelasan terlihat lebih tinggi karena bahan tambah yang mencair terlalu banyak di beberapa bagian permukaan benda kerja. Hal ini bia dihindari jika jarak elektroda ke benda kerja bisa lebih stabil sehingga hasil pengelasan lebih rata. 


\section{Pelaks anaan Tahun 2013}

Pada pelaksanaannya LKS-SMK DIY Bidang Pengelasan Tahun 2013 diikuti 12 peserta yang berasal dari SMK se-Daerah Istimewa Yogyakarta. Pekerjaan yang di- lakukan adalah membuat sambungan kampuh "V" (V Butt Joint) posisi horisontal (2G). Berikut data hasil LKS bidang pengelasan tahun 2013 dapat dilihat dalam table

Tabel 6. Penilaian Hasil Pekerjaan Sambungan Las LKS 2013

\begin{tabular}{|c|c|c|c|c|c|c|c|c|c|c|c|c|c|}
\hline \multirow{2}{*}{ No. } & \multirow{2}{*}{$\begin{array}{l}\text { Skor } \\
\text { Maks }\end{array}$} & \multicolumn{12}{|c|}{ Nomor Urut Peserta } \\
\hline & & 1 & 2 & 3 & 4 & 5 & 6 & 7 & 8 & 9 & 10 & 11 & 12 \\
\hline 1 & 0,2 & 0,2 & 0,2 & 0 & 0 & 0 & 0 & 0,2 & 0 & 0 & 0,2 & 0 & 0 \\
\hline 2 & 0,2 & 0 & 0 & 0 & 0 & 0 & 0 & 0 & 0 & 0 & 0 & 0 & 0,1 \\
\hline 3 & 0,3 & 0,3 & 0,3 & 0 & 0 & 0 & 0,3 & 0,3 & 0 & 0,3 & 0 & 0 & 0 \\
\hline 4 & 0,2 & 0,2 & 0,2 & 0 & 0 & 0 & 0 & 0 & 0 & 0,2 & 0 & 0,2 & 0,2 \\
\hline 5 & 0,3 & 0,3 & 0 & 0,3 & 0 & 0 & 0 & 0 & 0,3 & 0,3 & 0 & 0 & 0,3 \\
\hline 6 & 0,3 & 0,3 & 0,3 & 0 & 0 & 0 & 0 & 0,3 & 0 & 0,3 & 0 & 0,1 & 0,3 \\
\hline 7 & 0,3 & 0,3 & 0,3 & 0 & 0 & 0,3 & 0,3 & 0,1 & 0 & 0,3 & 0,3 & 0,2 & 0,3 \\
\hline 8 & 0,3 & 0,3 & 0,3 & 0 & 0 & 0,3 & 0 & 0,3 & 0,3 & 0,3 & 0,3 & 0 & 0,1 \\
\hline 9 & 0,3 & 0,2 & 0,2 & 0,1 & 0 & 0 & 0,2 & 0 & 0 & 0,3 & 0 & 0 & 0,3 \\
\hline 10 & 0,3 & 0,3 & 0 & 0,2 & 0,2 & 0,3 & 0 & 0,3 & 0,3 & 0,3 & 0,3 & 0,2 & 0,3 \\
\hline 11 & 0,3 & 0,3 & 0,2 & 0,3 & 0 & 0 & 0,1 & 0,3 & 0 & 0,3 & 0 & 0 & 0,3 \\
\hline 12 & 0,3 & 0,3 & 0 & 0 & 0 & 0 & 0 & 0,3 & 0 & 0,3 & 0 & 0,1 & 0 \\
\hline 13 & 0,3 & 0,3 & 0,3 & 0 & 0 & 0 & 0 & 0,3 & 0 & 0 & 0 & 0,2 & 0,2 \\
\hline 14 & 0,2 & 0,2 & 0 & 0 & 0 & 0 & 0 & 0,2 & 0 & 0 & 0,2 & 0 & 0,2 \\
\hline \multirow[t]{3}{*}{15} & 0,2 & 0,2 & 0,2 & 0,2 & 0,2 & 0,2 & 0 & 0,2 & 0,2 & 0,2 & 0,2 & 0,2 & 0,2 \\
\hline & Jumlah & 3,6 & 2,5 & 1,1 & 0,4 & 1,1 & 0,9 & 2,8 & 1,1 & 3,1 & 1,5 & 1,2 & 2,8 \\
\hline & Nilai & 90 & 62,5 & 27,5 & 10 & 27,5 & 22,5 & 70 & 27,5 & 77,5 & 37,5 & 30 & 70 \\
\hline
\end{tabular}

Dari tabel hasil las LKS-SMK Bidang Las Provinsi DIY Tahun 2013 di atas terlihat beberapa butir penilaian hasil las yaitu membuat sambungan kampuh "V" posisi $2 \mathrm{G}$ peserta yang lulus kurang dari setengah jumlah peserta yang mengikuti LKS-SMK Bidang Las Provinsi DIY Bidang Las Provinsi DIY Tahun 2013, seperti yang ditampilkan di gambar berikut:

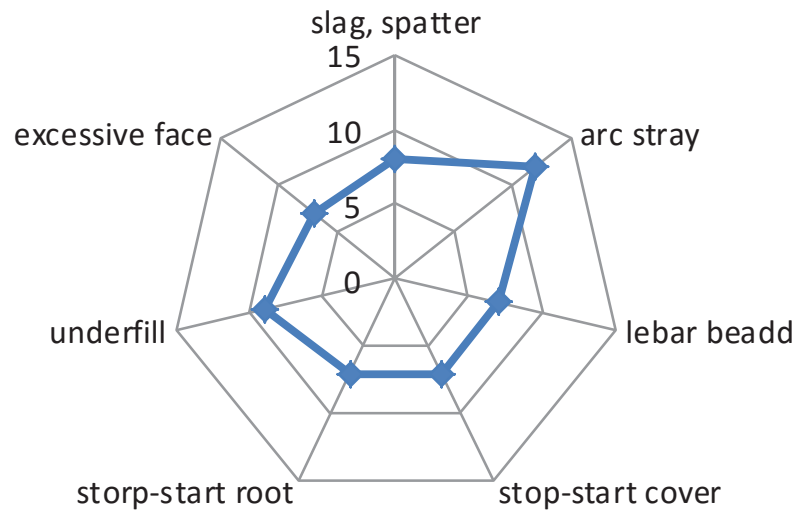

Gambar 6. Kesalahan yang Banyak Terjadi pada Hasil Las 2 G 
Gambar di atas menunjukkan bahwa kesalahan yang banyak dilakukan peserta LKSSMK Bidang Las Provinsi DIY Tahun 2013 yakni membuat sambungan kampuh "V" posisi horizontal (2G) meliputi beberapa kesalahan atau cacat seperti digambarkan dan di jelaskan di bawah ini:

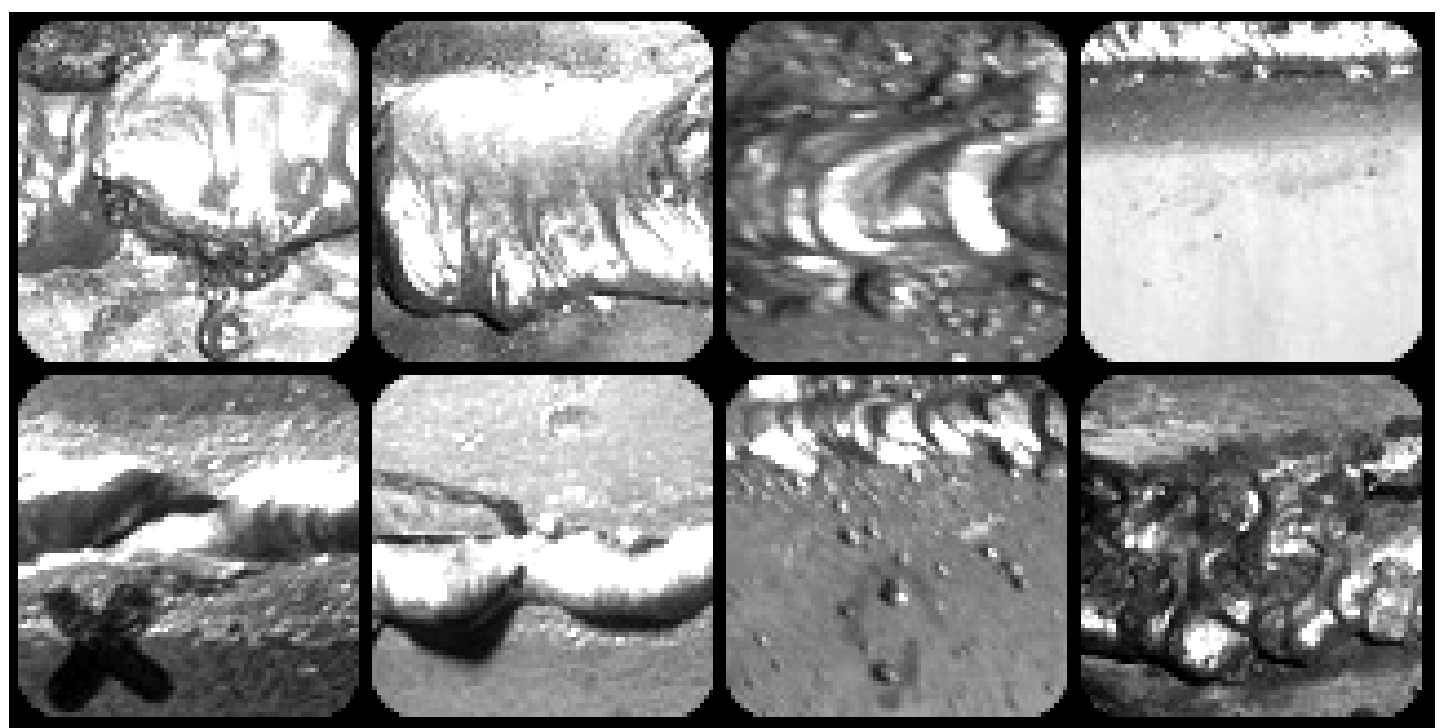

Gambar 7. Foto Kesalahan yang Banyak Terjadi pada Hasil Las 2G

\section{Kebebasan benda kerja dari Slag, Smoke, dan Spatter.}

Dari gambar 6 terlihat setengah dari jumlah peserta LKS-SMK Bidang Las Provinsi DIY Tahun 2013 yang hasil lasnya bebas dari slag, smoke, dan spatter. Hal ini menunjukkan bahwa masih banyak peserta yang belum memenuhi kriteria hasil las bebas dari Slag, smoke dan spatter. Cacat ini disebabkan oleh arus yang terlalu besar, salah jenis arus, dan salah polaritas. Oleh karena itu, pemilihan dan penentuan arus yang tepat akan mengurangi terjadinya slag dan spatter.

\section{Kebebas an dari Arc stary}

Berdasarkan gambar 6 terlihat bahwa semua hasil pengelasan peserta terdapat arc stray. Arc stray merupakan cacat las yang terjadi pada saat proses menyalakan elektroda. Kesalahan ini dapat menyebabkan rusaknya benda kerja, oleh karena itu kesalahan ini harus dihindari.
Variasi le bar beadd tidak mele bihi 2 mm.

Dari gambar 6 terlihat bahwa peserta yang lulus pada butir 3 yaitu variasi lebar beadd tidak melebihi $2 \mathrm{~mm}$ hanya 5 orang, sedangkan yang lulus 7 orang. Ini menunjukkan bahwa mayoritas peserta belum memenuhi kriteria lebar beadd dengan toleransi $2 \mathrm{~mm}$. Kesalahan las ini desebabkan oleh tidak stabilnya gerakan/ayunan peserta saat melakukan pengelasan terutama pada saat mengelas cover pass. Untuk menghindari kesalahan ini dapat dilakukan dengan memperkuat tumpuan tangan dalam memegang elektroda pada saat mengelas serta membiasakan diri dengan membuat gerakan/ayunan yang stabil.

\section{Ke tinggian Stop-start pada pe rmukaan Cover} Pas s.

Berdasarkan gambar 6 diketahui bahwa mayoritas peserta LKS-SMK Bidang Las Provinsi DIY tidak lulus dalam penilaian hasil pada butir ini yakni ketinggian stop-start pada permukaan cover pass. Perbedaan ketinggian stop-start pada permukaan cover pass ini biasa 
terjadi karena memang butuh keahlian khusus untuk menghasilkan hasil pengelasan SMAW rata dan halus pada setiap sambungan ketika proses mengelas membutuhkan sambungan karena keterbatasan panjang elektroda. Perbedaan ketinggian stop-start ini biasanya terjadi karena pada saat melakukan pengelasan lagi setelah mengganti elektroda temperatur benda kerja menurun dan ketika melakukan pengelasan lagi seharusnya dilakukan pemanasan awal untuk meningkatkan temperatur sehingga pencairan elektroda bisa benar-benar menyatu dengan benda kerja.

\section{Ketinggian Stop-start pada permukaan Root Pass}

Jika dilihat dari gambar 6 , butir 4 dan 5 sama yaitu peserta yang tidak lulus 7 orang. Kesalahan pada butir 5 sama dengan butir 4 yaitu ketinggian stop-start, hanya saja pada butir 5 terdapat pada root pass. Secara prinsip kesalahan ini sama yaitu ketinggian stop-start yang melebihi kriteria. Hal yang harus dilakukan untuk menghindari ini adalah pada saat melakukan pengelasan root pass ketika akan menyambung, sebaiknya melakukan pemanasan awal pada bagian akhir pengelasan sebelumnya sehingga bahan tambah/elektroda yang akan digunakan dapat menyatu dengan pengelasan sebelumnya dan ketinggian stopstart relatif sama.

\section{Kebebas an dari cacat Underfill}

Berdasarkan gambar 6 di atas terlihat setengah hasil pengelasan dari jumlah peserta LKS-SMK Bidang Las Provinsi DIY Tahun 2013 mengalami cacat underfill. Kesalahan ini merupakan kesalahan yang terjadi pada permukaan las (cover pass) tidak penuh atau di bawah permukaan benda kerja. Hal ini terjadi karena cover pass dilakukan dengan gerakan terlalu cepat. Selain itu, juga bisa disebabkan karena pengelasan pada saat filler pass masih kurang.

\section{Kebebasan dari Excessive Face Reinforcement.}

Dari gambar 6 di atas dapat dilihat bahwa 10 dari 12 hasil pengelasan mengalami cacat excessive face reinforcement. Cacat ini adalah dapat dilihat dari terlalu tingginya beberapa bagian permukaan pengelasan. Kesalahan ini terjadi akibat tidak stabilnya jarak elektroda dengan benda kerja sehingga ketika elektroda terlalu dekat maka yang terjadi hasil pengelasan terlihat lebih tinggi karena bahan tambah yang mencair terlalu banyak di beberapa bagian permukaan benda kerja. Hal ini bisa dihindari jika jarak elektroda ke benda kerja bisa lebih stabil sehingga hasil pengelasan lebih rata.

Dari keseluruhan data kesalahan yang terjadi dalam lomba kompetensi siswa bidang pengelasan dapat dikategorisasikan sebagai berikut: (1) Kesalahan-kesalahan esensial yang dilakukan oleh siswa saat melakukan persiapan proses pengelasan (preparation welding) adalah dalam melakukan penyetelan arus yang masih terlalu besar, pemilihan jenis arus yang digunakan tidak sesuai, dan salah memilih jenis polaritas yang digunakan hal ini ditandai dengan masih banyak hasil sambungan las yang terdapat slag, smoke dan spatter. Kemudian masih ada yang menghasilkan sambungan dengan terdapat cacat incomplet penetration sebagai akibat kesalahan pembuatan root gap dan root face yang tidak sesuai dengan standar, meskipun juga dapat disebabkan oleh proses pengelasan yang salah. Demikian juga kesalahan preparation dalam membuat sambungan dimana pengikatan tidak dilakukan dengan baik sehingga saat proses pengelasan terjadi defleksi yang mengakibatkan terjadinya misaligment pada sambungan las. (2) Kesalahan-kesalahan esensial yang dilakukan oleh siswa saat melakukan proses pengelasan (welding) antara lain adalah penggunaan teknik ayunan yang tidak tepat, ditandai dengan kualitas rigi-rigi lasan yang kurang baik, pemilihan jenis elektroda yang tidak pas untuk masing masing pengelasan (root, filler dan cover pass) menghasilkan juga rigi yang tidak 
baik. Kesalahan las berupa lebar bead yang tidak sama disebabkan oleh tidak stabilnya gerakan/ayunan peserta saat melakukan pengelasan terutama pada saat mengelas cover pass. Untuk menghindari kesalahan ini dapat dilakukan dengan memperkuat tumpuan tangan dalam memegang elektroda pada saat mengelas serta membiasakan diri dengan membuat gerakan/ ayunan yang stabil. Perbedaan ketinggian stop-start pada permukaan cover pass ini biasa terjadi karena memang butuh keahlian khusus untuk menghasilkan hasil pengelasan SMAW rata dan halus pada setiap sambungan ketika proses mengelas membutuhkan sambungan karena keterbatasan panjang elektroda. Perbedaan ketinggian stopstart ini biasanya terjadi karena pada saat melakukan pengelasan lagi setelah mengganti elektroda temperatur benda kerja menurun dan ketika melakukan pengelasan lagi seharusnya dilakukan pemanasan awal untuk meningkatkan temperatur sehingga pencairan elektroda bisa benar-benar menyatu dengan benda kerja. (3) Kesalahan-kesalahan esensial yang dilakukan oleh siswa pada proses perlakukan benda kerja pasca pengelasan hanya pada proses pembersihan saja karena menggunakan gerinda pada saat membersihkan spater yang merusak rigi-rigi las. Namun dalam jumlah yang sedikit. Penggunaan air sebagai bahan pendingin sudah tidak digunakan sesuai dengan ketentuan lomba. (4) Gambaran kualitas benda kerja/sambungan las hasil LKS bidang pengelasan SMK se DIY Jika dilihat rata-rata nilai proses LKS-SMK Bidang Las Provinsi DIY Tahun 2012 dan 2013 terlihat bahwa peserta telah mengikuti prosedur selama proses pengelasan dengan cukup baik. Peserta LKSSMK Bidang Las Provinsi DIY Tahun 2012 dan 2013 secara prosedur proses pengelasan sudah cukup memenuhi standar. Namun jika melihat rata-rata nilai hasil las LKS-SMK Bidang Las Provinsi DIY Tahun 2012 terlihat masih rendah. Ini terjadi karena peserta yang mendapat nilai di atas 80 hanya 4 peserta, sementara yang lain masih di bawah nilai 60 . Rata-rata nilai proses las LKS-SMK Bidang
Las Provinsi DIY Tahun 2013 rata-rata nilai hasil las terlihat masih rendah. Ini terjadi karena peserta yang mendapat nilai di atas 80 hanya 2 peserta, sementara yang lain masih di bawah nilai 60. Ini membuktikan bahwasannya teknik mengelas membutuhkan keterampilan khusus dari orangnya, walaupun secara prosedural sudah benar, namun jika skill dari peserta itu kurang baik maka hasilnya juga tidak maksimal. Selain itu, ini juga menunjukkan bahwasannya hanya beberapa peserta yang terbukti memiliki keterampilan dan mengikuti prosedur secara benar sehingga mendapatkan nilai yang maksimal.

Rata-rata nilai akhir LKS-SMK Bidang Las Provinsi DIY juga terlihat tidak lebih dari angka 60. Jika dilihat dari nilai akhir masingmasing peserta terlihat bahwa terjadi rentang yang cukup jauh antara peserta dengan nilai tertinggi dengan peserta lain di bawahnya. Ini memperlihatkan bahwa terjadi kesenjangan kompetensi yang cukup mencolok antara peserta dengan nilai tertinggi dengan peserta lainnya. Di samping perbedaan nilai yang mencolok juga masih ditemukan banyak cacat las yang mana menunjukkan kualitas siswa peserta yang belum memiliki kompetensi yang maksimal.

\section{SIMPULAN}

Berdasarkan hasil analisis yang dilakukan terhadap sambungan hasil pengelasan yang menjadi kekurangan dan kelemahan peserta dalam pelaksanaan LKS-SMK Bidang Las Provinsi DIY meliputi:

Dalam persiapan awal pengelasan (preparation), terlihat bahwa peserta LKS-SMK Bidang Las Provinsi DIY kurang pemahaman dan pengetahuan tentang menentukan persyaratan pengelasan khususnya dalam mengetahui kode las, memilih arus pengelasan, mengetahui jenis bahan logam, mengetahui jenis elektroda SMAW serta mengetahui fungsi alat keselamatan dan kesehatan kerja.

Dalam proses pengelasan peserta LKS-SMK Bidang Las Provinsi DIY masih terdapat 
beberapa peserta yang belum memenuhi prosedur pengelasan selama proses pengelasan berlangsung. Diantaranya adalah kesalahan dalam melakukan set up mesin SMAW, mengatur arus pengelasan dengan benar, memilih elektroda sesuai dengan jenis dan ketebalan benda kerja, kesalahan pada saat fit up, serta belum begitu sadar pentingnya penggunaan peralatan keselamatan dan kesehatan kerja.

Dalam proses pasca pengelasan tidak terlalu banyak kesalahan yang terjadi kecuali ada beberapa yang melakukan penggerindaan untuk membersihkan spatter sehingga merusak rigi

\section{DAFTAR RUJUKAN}

. 2005. Guidelines for Shielded

Metal Arc Welding. Boston: Miller 2005. Shielded Metal Arc Welding. Troy: Hobart Scholl of Welding Technology

Djojonegoro, Wardiman. 1998. Pengembangan Sumberdaya Manusia melalui SMK. Jakarta: PT Jayakarta Agung Offset

Kementerian Pendidikan dan Kebudayaan. 2012. Lomba Keterampilan Siswa Tingkat Nasional, Lembar Kisi-kisi Bidang Welding. Jakarta: Direktorat Pembinaan SMK Jenderal Pendidikan Menengah

Kennedy, GA., 2004. Welding Technologi. Indianapolis: The Bobbs-Merrill Company. Inc. las, dalam penggunaan air sebagai media pendingin sudah tidak lagi digunakan peserta.

Dari penilaian hasil las LKS-SMK Bidang Las Provinsi DIY menunjukkan beberapa kasus yang terjadi dan menjadi kekurangan dan kegagalan peserta antara lain kebebasan benda kerja dari slag, spatter dan arc stray, variasi lebar hasil las melebihi $2 \mathrm{~mm}$, kebebasan benda kerja dari cacat incomplete penetration or root fusion porosity, kebebasan benda kerja dari cacat stop-start pada permukaan cover pass dan root pass, kebebasan benda kerja dari cacat under fill, serta kebebasan benda kerja dari cacat excessive face reinforcement. 